\title{
Socio-economic determinants of breed choice - A case of Sahiwal vs. crossbred in India
}

\author{
Gunjan Bhandari* and B.S. Chandel
}

Division of Dairy Economics, Statistics and Management

ICAR-NDRI, Karnal-132001, Haryana, India

*Corresponding author

\section{A B S T R A C T}

Keywords

Conservation,

Cattle breed,

Sahiwal, Socio-

economic

determinants,

Discriminant

Analysis.

\section{Article Info}

Accepted:

15 December 2019

Available Online:

20 January 2020
Designing of effective conservation policy necessitates a clear understanding of the socio-economic factors that leads to the adoption of a particular cattle breed by the dairy farmers. The present study uses descriptive statistics and discriminant analysis to identify the socioeconomic determinants of breed choice with specific reference to Sahiwal breed.Prominent breeding tract of Sahiwal in India was purposively selected as the study area and required primary data was collected from 168 dairy farmers comprising 84 Sahiwal rearing farmers and 84 crossbred rearing farmers. The most important variables discriminating the two groups were herd size,education of household head, proportion of buffalo in total herd and livelihood diversification. Bigger herd size generally indicated Sahiwal rearing household. Household heads with higher level of education and higher proportion of buffaloes in the herd were more likely to keep crossbreds. Number of households involved in alternate occupation like business and jobs were more in Sahiwal rearing group.

\section{Introduction}

India is immensely rich in bovine diversity and possess one-ninth of cattle germplasm. There are 43 well defined breeds of cattle in India out of which Sahiwal, Rathi, Gir, Tharparkar and Red Sindhi are known for their good milk yield. These breeds evolved over the centuries in their breeding tract and are thus well adapted to the local conditions. They are sturdy, are endowed with quality of heat tolerance, resistance to diseases and ability to thrive under extreme nutritional stress. They are also known for their good temperament and ease of calving. But in the recent decades, the comparatively lower milk 
yield of these breeds has led to their substitution with crossbreds and high milk yielding exotic breeds. Though, milk yield of crossbreds is goodbut they have not yet fully adapted to Indian conditions and their management is quite expensive. Still, they are now widespread and have diluted the gene pool of indigenous breeds to a great extent.

The declining population of indigenous breeds and the importance of their adaptability traits for sustainable dairy farming have attracted the attention of Government of India which has now directed efforts towards their conservation. Designing of any effective conservation policy necessitates a clear understanding of the socio-economic factors that influences the adoption of a particular cattle breed by the dairy farmers. Thus, the present study attempts to identify the socioeconomic determinants of breed choice with specific reference to Sahiwal breed.

\section{Materials and Methods}

\section{Study breed}

Sahiwal breed was purposively selected for the study because it is the highest milk yielding breed among the indigenous cattle in India but is still facing threat of extinction in its own homeland.

\section{Study area}

The study was carried out in the breeding tract of Sahiwal in India comprising of Sri Ganganagar district (Rajasthan), Fazilka district (Punjab) and Sirsa district (Haryana). This region was purposively selected as due to prolonged association with the native community, Sahiwal breed is well known and forms a part of local landscape, tradition and customs. Despite this, the area has observed a major decline in the number of indigenous cattle and a subsequent rise in the population of crossbred which makes it an ideal choice for the study.

\section{Sampling Framework}

Multi stage sampling procedure was adopted. At the first stage, entire breeding tract of Sahiwal in India comprising of Fazilka district (Punjab), Sri Ganganagar district (Rajasthan) and Sirsa district (Haryana) was selected purposively. After that, based on field information two blocks having higher number of Sahiwal cattle were purposively selected from each district and from each block again two villages were selected. From each village 7 Sahiwal rearing and 7 non- Sahiwal rearing dairy farmers were selected randomly. Thus, a total of 168 dairy farmers comprising 84 Sahiwal rearing and 84 crossbred rearing were selected from twelve villages.

Data Collection: Primary data was collected by personally interviewing the respondents using a pretested structured schedule developed for the purpose. Information related to various socio-economic parameters of the householdswas collected from the primary sources.

\section{Analytical tools}

Descriptive statistics and discriminant analysis were used to identify the socio-economic variables affecting the choice of cattle breed of the dairy farmers.Discriminant Function Analysis (DA) undertakes the same task as multiple linear regression by predicting an outcome in cases where dependent variable is categorical. Independent variables can be of any type (continuous, categorical or both). It is used to distinguish distinct sets of observations and allocate new observations to previously defined groups. This analysis was used to know the variables which discriminate Sahiwal rearing farmers from crossbred rearing farmers. 
Stepwise discriminant function analysis was carried out in SPSS. To identify a subset of variables which best discriminate between the $\mathrm{K}$ populations, an $\mathrm{F}$ statistic based on one way analysis of variance test was used to choose the variables. The variable for which the mean values in the $\mathrm{K}$ population were "most different" was identified. The value of structure and standardized coefficients helped in assessing the importance of each independent variable's unique contribution to the discriminant function. Wilk's lambda was used to check the significance of the model.

The variables considered for discriminant function analysis were:

$\mathrm{X}_{1}=$ Herd size (number)

$\mathrm{X}_{2}=$ Education of household head (in years).

$\mathrm{X}_{3}=$ Proportion of buffalo in total herd (percentage).

$\mathrm{X}_{4}=$ Livelihood diversification, $1=$ if any other source of income along with agriculture and livestock rearing is present, otherwise 0 .

$\mathrm{X}_{5}=$ Size of the land holdings (in acres).

$\mathrm{X}_{6}=$ Annual household income (in Rs. / capita).

$\mathrm{X}_{7}=$ Family Size (number).

$\mathrm{X}_{8}=$ Presence of pastures, 1 if available, otherwise 0.

$\mathrm{X}_{9}=$ Age of household head (in years).

Score of one for farmers who were rearing Sahiwal and zero for those who belonged to crossbred rearing households was given.

\section{Results and Discussion}

Various socio-economic characteristics of sample households like age, education, family size, land holding, herd size etc. were analyzed and results are presented as below.

\section{General profile of the households}

Details related to the age and education of the household head is presented in the following
tables.Table 1 shows the age of household head in different categories. The average age of household head was 45.13 years and there was no major difference between different areas. The average age of Sahiwal and crossbred rearing farmers was found to be 45.43 and 44.83 years, respectively. Thus, in respect of age there was no major difference between the two types of dairy farmers. This indicates that preferences of dairy farmers for cattle breed are different even within the same age group.

Coming to the educational qualification, on an average, head of the crossbred rearing households were more educated than the ones who were rearing Sahiwal (Table 2). This difference was most prominent in the Fazilka region. Education provides exposure to the literature, thus, more educated ones are likely to understand the package of practices and readily adopt crossbred. Unlike other areas Sahiwal rearing farmers were more qualified in Sirsa. This region has traditionally been under the buffalo belt. People started rearing Sahiwal breed here few years back after getting information about its additional attributes.

Details of family size are presented in Table 3. Number of family members in Sahiwal rearing households was marginally higher than in crossbred rearing households. Sirsa was an exception in this case also.

Ganganagar and Fazilka district share border with Pakistan. This area is quite diverse in terms of religion and has considerable followers of Hinduism, Islam and Sikhism. Table 4 presents details regarding the religion of sample households. Out of the total households' surveyed 88 (52\%) households belonged to Hindu community, 31 (19\%) to Muslim community and rest 49 (29\%) to Sikh community. 
Majority of the Hindu (60\%) and Sikh (67\%) households were rearing crossbred whereas cent percent Muslims households surveyed were rearing Sahiwal breed. This indicates strong preference of Muslim community for Sahiwal breed in the sample region. In earlier times, Muslim community of this region used to be nomadic. They kept huge number of livestock and use to seasonally migrate in search of fresh pastures. Indigenous breeds specifically Sahiwal was preferred by them due to its suitability for pastoral way of animal husbandry and better milk yield. Now, most of the people have settled down but the herd size maintained by them still ranges from 50 to 200. Livestock rearing is their main source of livelihood and they generally do not own any agricultural land. They still continue to prefer Sahiwal breed over crossbred because of its additional attributes and its suitability to their low input system.

Land holding and livestock details of the sample households

Table 5 presents land holding details of the sample households. On an average, Sahiwal rearing households owned less land than the crossbred rearing households. This difference was most prominent in the Fazilka region as all the farmers rearing Sahiwal in that area belonged to Muslim community who were not having any land holding. Thesingurajaet al. (2017) in their study of Pulikulam cattle, one of the indigenous cattle breed in Tamil Nadu also found that majority of indigenous cattle rearers were landless. On the contrary in Sirsa, Sahiwal rearing farmers were having more land.

Table 6 shows average number of livestock kept by the sample household. Taking all the three areas together, number of livestock kept by Sahiwal rearing farmers was considerably higher than the crossbred rearing farmers. This was mainly because of Fazilka region where the Sahiwal rearing farmers were maintaining huge herd. In Ganganagar and Sirsa also relative number of livestock kept by Sahiwal rearing farmers was more but the difference was not significant.

Average percentage composition of milch animals in sample households is displayed in Table 7. In Sahiwal rearing households, highest proportion of milch animal was of Sahiwal (46.58\%) followed by other indigenous breeds $(35.72 \%)$, buffaloes $(10.30 \%)$ and crossbred $(7.40 \%)$. Crossbred cattle grabbed the maximum share $(65.82 \%)$ in crossbred rearing households followed by buffalo (20.11) and local indigenous breeds other than Sahiwal (14.14\%).

Crossbred rearing households were having higher proportion of buffaloes than the Sahiwal rearing households in all the areas. People in the study area preferred to use buffalo milk for their own domestic consumption rather than using milk of crossbred. Both Sahiwal and crossbred rearing farmers were keeping good proportion of other indigenous cows in Ganganagar whereas their proportion in Sirsa households was quite less.

\section{Occupation and income status of the sample households}

Table 8 presents details of the households involved in various occupations other than dairy farming. As for our study we purposively selected dairy farmers so cent percent of households in any category were involved in livestock rearing. Livestock rearing and crop production were found to be the main source of livelihood.All the crossbred rearing farmers in Fazilka and Ganganagar area were having land and they were involved in crop production. Whereas, relatively less number of Sahiwal rearing households were practicing agriculture in these areas. The percentage of dairy farmers who were cultivating crops was less in the case of Sahiwal rearing group than 
in crossbred ones in Sirsa also. Number of households involved in alternate occupation like business and jobs were more in Sahiwal rearing group.

Table 9 shows the average annual income of the sample households. It can be seen that average annual income of Sahiwal rearing farmers was more in Sirsa. This is because in the case of Sirsa, households who were economically better off ventured in Sahiwal rearing as price of pure Sahiwal was quite high in the region and only financially well households can afford it. Larger land holding size and livelihood diversification of these households support their economic soundness.

Dairy farmers in Ganganagar and Fazilka were traditionally rearing Sahiwal from a long time. In both of these areas land holding of Sahiwal rearing farmers was comparatively less than crossbred rearing farmers which translates to less revenue. But in Ganganagar, Sahiwal milk was receiving premium over crossbred which probably compensated for the low income from land. Some of the dairy farmers in Fazilka were also receiving price premium for Sahiwal's milk but as they were not having any land holding so their annual income was comparatively less than their crossbred rearing counterparts. Still, larger herd size maintained by them reduced the income gap to a large extend. Overall, the annual income of Sahiwal farmers was comparatively more than the crossbred rearing farmers. On the contrary, Vermaet al. (2014) in their study reported poor economic status of dairy farmers rearing Kherigarh, an indigenous breed of cattle.

Factors discriminating Sahiwal rearing and crossbred rearing dairy farmers

In order to identify the important variables with regard to their power to discriminate between the Sahiwal and crossbred rearing farmers, the discriminant function analysis was used. Before conducting discriminant analysis, correlation between various independent variables was calculated. No significant multicollinearity was found. Following this a stepwise discriminant analysis was conducted which identified foursignificant discriminating variables-herd size $\left(\mathrm{X}_{1}\right)$, education of household head $\left(\mathrm{X}_{2}\right)$, proportion of buffalo in total herd $\left(\mathrm{X}_{3}\right)$ and livelihood diversification $\left(\mathrm{X}_{4}\right)$. Thus, out of nine only these four variables were used in the analysis (table 10). The estimated function was as follows,

$Z=0.698 X_{1}-0.354 X_{2}-0.266 X_{3}+0.484 X_{4}$

Sahiwal rearing households were generally maintaining higher herd size. This was in contrast with the results of Sharma et al. (2005) who reported that in Udaipur large herd size owners had more favorable opinion than small herd size owners towards rearing crossbred cattle.Head of the crossbred rearing households were likely to be more educated than the ones who were rearing Sahiwal. Education might have provided better exposure to them leading to early adoption of the new breeds while the others continue with the conventional ones.

Crossbred rearing households were also having higher proportion of buffaloes in their herd than Sahiwal rearing households. The former households preferred to use buffalo milk for their own domestic consumption rather than using milk of crossbred whereas milk of Sahiwal was available for the latter ones for own consumption. Number of households involved in alternate occupation like business and jobs were comparatively more in Sahiwal rearing group. Diversity in occupation of indigenous cattle farmers was also observed by Naveen et al. (2019) in the case of Gir cattle in Karnataka. 
The structure coefficients are also reported in table 10. They are ordered from highest to lowest by the size of the loading. It is evident that the most important discriminating variables on the basis of structure coefficients were same- herd size, education of household head, proportion of buffalo in total herd and livelihood diversification- each one having a coefficient more than 0.3 . It can be observed from table 11 that there is considerable difference between canonical means of the two groups which indicates that the two groups can be differentiated from one another.

Table 12 shows different measures of significance. The Wilk's value (0.776) revealed that discriminant function was highly significant [0.000] and displayed a canonical correlation of 0.474 . This canonical coefficient was interpreted by squaring it, which is 0.23 , thus, 23 per cent of the variation in the dependent variable is explained by this model which includes only four variables.

Hence it is concluded that the current study highlights the major socio-economic differences between the households rearing Sahiwal cattle and crossbreds and also attempts to discuss how these factors influence the ownership of the cattle breeds. More educated farmers generally readily experiment with their breed choice and in the past these farmers were the first ones to substitute indigenous breeds with the crossbreds. In Sirsa, the more educated farmers have started to switch back to indigenous breeds from crossbreds. Thus, care is required to ensure dissemination of correct and reliable information. Traditional keepers of Sahiwal in the study area were strongly inclined towards Sahiwal breed and had good animals but most of them rely on conventional practices. Awareness and exposure to the scientific practices can help in improving the animal health and milk yield along with retention of animal purity.Sahiwal rearing households were generally maintaining bigger herd size. The economics of indigenous cattle in relation to the herd size can be further investigated. It was also clearly evident that milk of indigenous cattle or buffalo was preferred more than the crossbreds by the households for domestic consumption. More research can be done to see if this preference for milk can be translated to price premium by the consumers.

Table.1 Average age of the household head (years)

\begin{tabular}{|c|c|c|c|}
\hline Region & SRF & CRF & Overall \\
\hline Sri Ganganagar & $\begin{array}{r}49.25 \\
(35.00-69.00)\end{array}$ & $\begin{array}{r}45.29 \\
(30.00-68.00)\end{array}$ & $\begin{array}{r}47.27 \\
(30.00-69.00)\end{array}$ \\
\hline Fazilka & $\begin{array}{r}42.50 \\
(32.00-55.00)\end{array}$ & $\begin{array}{r}42.32 \\
(28.00-66.00)\end{array}$ & $\begin{array}{r}42.41 \\
(28.00-66.00)\end{array}$ \\
\hline Sirsa & $\begin{array}{r}44.54 \\
(25.00-64.00)\end{array}$ & $\begin{array}{r}46.89 \\
(25.00-68.00)\end{array}$ & $\begin{array}{r}45.71 \\
(25.00-68.00)\end{array}$ \\
\hline Overall & $\begin{array}{r}45.43 \\
(25.00-69.00)\end{array}$ & $\begin{array}{r}44.83 \\
(25.00-68.00)\end{array}$ & $\begin{array}{r}45.13 \\
(25.00-69.00)\end{array}$ \\
\hline
\end{tabular}

Figures in parenthesis show the range within which the age varies. $\mathrm{SRF}=$ Sahiwal Rearing Farmers, $\mathrm{CRF}=$ Crossbred Rearing Farmers 
Table.2 Educational qualification of household head

\begin{tabular}{|c|c|c|c|c|c|c|c|}
\hline Region & Category* & Illiterate & Primary & Secondary & $\begin{array}{l}\text { Higher } \\
\text { Secondary }\end{array}$ & Graduate & Total \\
\hline \multirow[t]{3}{*}{$\begin{array}{l}\text { Sri } \\
\text { Ganganagar }\end{array}$} & SRF & $\begin{array}{l}2 \\
(7.14)\end{array}$ & $\begin{array}{l}15 \\
(53.57)\end{array}$ & $\begin{array}{l}8 \\
(28.57)\end{array}$ & $\begin{array}{l}3 \\
(10.71)\end{array}$ & $\begin{array}{l}0 \\
(0.00)\end{array}$ & $\begin{array}{l}28 \\
(100.00)\end{array}$ \\
\hline & $\mathrm{CRF}$ & $\begin{array}{l}0 \\
(0.00)\end{array}$ & $\begin{array}{l}10 \\
(35.71)\end{array}$ & $\begin{array}{l}9 \\
(32.14)\end{array}$ & $\begin{array}{l}5 \\
(17.86)\end{array}$ & $\begin{array}{l}4 \\
(14.29)\end{array}$ & $\begin{array}{l}28 \\
(100.00)\end{array}$ \\
\hline & Overall & $\begin{array}{l}2 \\
(3.57)\end{array}$ & $\begin{array}{l}25 \\
(44.64)\end{array}$ & $\begin{array}{l}17 \\
(30.36)\end{array}$ & $\begin{array}{l}8 \\
(14.29)\end{array}$ & $\begin{array}{l}4 \\
(7.14)\end{array}$ & $\begin{array}{l}56 \\
(100.00)\end{array}$ \\
\hline \multirow[t]{3}{*}{ Fazilka } & SRF & $\begin{array}{l}3 \\
(10.71)\end{array}$ & $\begin{array}{l}19 \\
(67.86)\end{array}$ & $\begin{array}{l}5 \\
(17.86)\end{array}$ & $\begin{array}{l}1 \\
(3.57)\end{array}$ & $\begin{array}{l}0 \\
(0.00)\end{array}$ & $\begin{array}{l}28 \\
(100.00)\end{array}$ \\
\hline & $\mathrm{CRF}$ & $\begin{array}{l}0 \\
(0.00)\end{array}$ & $\begin{array}{l}6 \\
(21.43)\end{array}$ & $\begin{array}{l}9 \\
(32.14)\end{array}$ & $\begin{array}{l}8 \\
(28.57)\end{array}$ & $\begin{array}{l}5 \\
(17.86)\end{array}$ & $\begin{array}{l}28 \\
(100.00)\end{array}$ \\
\hline & Overall & $\begin{array}{l}3 \\
(5.36)\end{array}$ & $\begin{array}{l}25 \\
(44.64)\end{array}$ & $\begin{array}{l}14 \\
(25.00)\end{array}$ & $\begin{array}{l}9 \\
(16.07)\end{array}$ & $\begin{array}{l}5 \\
(8.93)\end{array}$ & $\begin{array}{l}56 \\
(100.00)\end{array}$ \\
\hline \multirow[t]{3}{*}{ Sirsa } & SRF & $\begin{array}{l}0 \\
(0.00)\end{array}$ & $\begin{array}{l}5 \\
(17.86)\end{array}$ & $\begin{array}{l}13 \\
(46.43)\end{array}$ & $\begin{array}{l}4 \\
(14.29)\end{array}$ & $\begin{array}{l}6 \\
(21.43)\end{array}$ & $\begin{array}{l}28 \\
(100.00)\end{array}$ \\
\hline & $\mathrm{CRF}$ & $\begin{array}{l}2 \\
(7.14)\end{array}$ & $\begin{array}{l}7 \\
(25.00)\end{array}$ & $\begin{array}{l}14 \\
(50.00)\end{array}$ & $\begin{array}{l}2 \\
(7.14)\end{array}$ & $\begin{array}{l}3 \\
(10.71)\end{array}$ & $\begin{array}{l}28 \\
(100.00)\end{array}$ \\
\hline & Overall & $\begin{array}{l}2 \\
(3.57)\end{array}$ & $\begin{array}{l}12 \\
(21.43)\end{array}$ & $\begin{array}{l}27 \\
(48.21)\end{array}$ & $\begin{array}{l}6 \\
(10.71)\end{array}$ & $\begin{array}{l}9 \\
(16.07)\end{array}$ & $\begin{array}{l}56 \\
(100.00)\end{array}$ \\
\hline \multirow[t]{3}{*}{ Overall } & SRF & $\begin{array}{l}5 \\
(5.95)\end{array}$ & $\begin{array}{l}39 \\
(46.43)\end{array}$ & $\begin{array}{l}26 \\
(30.95)\end{array}$ & $\begin{array}{l}8 \\
(9.52)\end{array}$ & $\begin{array}{l}6 \\
(7.14)\end{array}$ & $\begin{array}{l}84 \\
(100.00)\end{array}$ \\
\hline & CRF & $\begin{array}{l}2 \\
(2.38)\end{array}$ & $\begin{array}{l}23 \\
(27.38)\end{array}$ & $\begin{array}{l}32 \\
(38.10)\end{array}$ & $\begin{array}{l}15 \\
(17.86)\end{array}$ & $\begin{array}{l}12 \\
(14.29)\end{array}$ & $\begin{array}{l}84 \\
(100.00)\end{array}$ \\
\hline & Overall & $\begin{array}{l}7 \\
(4.17)\end{array}$ & $\begin{array}{l}62 \\
(36.90)\end{array}$ & $\begin{array}{l}58 \\
(34.52)\end{array}$ & $\begin{array}{l}23 \\
(13.69)\end{array}$ & $\begin{array}{l}18 \\
(10.71)\end{array}$ & $\begin{array}{l}168 \\
(100.00)\end{array}$ \\
\hline
\end{tabular}

Figures in parenthesis show the percentage of row total.

*SRF= Sahiwal Rearing Farmers, $\mathrm{CRF}=$ Crossbred Rearing Farmers

Table.3 Family size of the sample households

\begin{tabular}{|l|l|l|l|}
\hline Region & SRF & CRF & Overall \\
\hline Sri Ganganagar & 6.36 & 5.46 & 5.91 \\
& $(3.00-14.00)$ & $(3.00-9.00)$ & $(3.00-14.00)$ \\
\hline Fazilka & 5.61 & 5.50 & 5.55 \\
& $(3.00-9.00)$ & $(2.00-10.00)$ & $(2.00-10.00)$ \\
\hline Sirsa & 5.57 & 5.43 & 5.50 \\
\hline Overall & $(3.00-12.00)$ & $(3.00-9.00)$ & $(3.00-12.00)$ \\
& 5.85 & 5.46 & 5.65 \\
& $(3.00-14.00)$ & $(2.00-10.00)$ & $(2.00-14.00)$ \\
\hline
\end{tabular}

Figures in parenthesis show the range within which the family size varies.

$\mathrm{SRF}=$ Sahiwal Rearing Farmers, $\mathrm{CRF}=$ Crossbred Rearing Farmers 
Table.4 Religion wise distribution of sample households

\begin{tabular}{|c|c|c|c|c|c|c|c|c|}
\hline \multirow{2}{*}{$\begin{array}{l}\text { Sl. } \\
\text { No. }\end{array}$} & \multirow[t]{2}{*}{ District } & \multirow[t]{2}{*}{ Religion } & \multicolumn{2}{|c|}{ Total } & \multicolumn{2}{|c|}{ SRF } & \multicolumn{2}{|c|}{ CRF } \\
\hline & & & No. & $\%$ & No. & $\%$ & No. & $\%$ \\
\hline \multirow[t]{3}{*}{1.} & \multirow{3}{*}{$\begin{array}{l}\text { Sri } \\
\text { Ganganagar }\end{array}$} & Hindu & 39 & 100 & 22 & 56.41 & 17 & 43.59 \\
\hline & & Muslim & 4 & 100 & 4 & 100.00 & 0 & 0.00 \\
\hline & & Sikh & 13 & 100 & 2 & 15.38 & 11 & 84.62 \\
\hline \multirow[t]{3}{*}{2.} & \multirow[t]{3}{*}{ Fazilka } & Hindu & 21 & 100 & 1 & 4.76 & 20 & 95.24 \\
\hline & & Muslim & 27 & 100 & 27 & 100.00 & 0 & 0.00 \\
\hline & & Sikh & 8 & 100 & 0 & 0.00 & 8 & 100.00 \\
\hline \multirow[t]{3}{*}{3.} & \multirow[t]{3}{*}{ Sirsa } & Hindu & 28 & 100 & 14 & 50.00 & 14 & 50.00 \\
\hline & & Muslim & 0 & 0 & 0 & 0.00 & 0 & 0.00 \\
\hline & & Sikh & 28 & 100 & 14 & 50.00 & 14 & 50.00 \\
\hline \multirow[t]{3}{*}{4.} & \multirow[t]{3}{*}{ Overall } & Hindu & 88 & 100 & 37 & 42.05 & 51 & 57.95 \\
\hline & & Muslim & 31 & 100 & 31 & 100.00 & 0 & 0.00 \\
\hline & & Sikh & 49 & 100 & 16 & 32.65 & 33 & 67.35 \\
\hline
\end{tabular}

SRF $=$ Sahiwal Rearing Farmers, $C R F=$ Crossbred Rearing Farmers

Table.5 Average land holding size per sample household (in acres/ household)

\begin{tabular}{|l|l|l|l|}
\hline Sl. No. & District & SRF & CRF \\
\hline 1. & Sri Ganganagar & 21.00 & 25.00 \\
\hline 2. & Fazilka & 0.29 & 15.50 \\
\hline 3. & Sirsa & 14.32 & 11.54 \\
\hline 4. & Overall & 12.00 & 17.00 \\
\hline
\end{tabular}

SRF $=$ Sahiwal Rearing Farmers, $C R F=$ Crossbred Rearing Farmers

Table.6 Average number of livestock per sample household

\begin{tabular}{|c|c|c|c|c|c|c|c|c|}
\hline $\begin{array}{ll}\text { Type } & \text { of } \\
\text { farmers }\end{array}$ & State & Sahiwal & Desi & Crossbred & Buffalo & Goat & Camel & Total \\
\hline \multirow{4}{*}{$\begin{array}{l}\text { Sahiwal } \\
\text { rearing } \\
\text { farmers }\end{array}$} & Ganganagar & 7.46 & 5.75 & 0.18 & 1.04 & 0.00 & 0.72 & 15.14 \\
\hline & Fazilka & 12.00 & 55.61 & 0.04 & 1.93 & 2.82 & 0.00 & 72.46 \\
\hline & Sirsa & 3.29 & 0.07 & 1.04 & 0.93 & 0.00 & 0.07 & 5.39 \\
\hline & Overall & 7.58 & 20.48 & 0.42 & 1.30 & 0.94 & 0.26 & 31.00 \\
\hline \multirow{4}{*}{$\begin{array}{l}\text { Crossbred } \\
\text { rearing } \\
\text { farmers }\end{array}$} & Ganganagar & 0.00 & 6.89 & 3.18 & 1.11 & 0.00 & 0.46 & 11.64 \\
\hline & Fazilka & 0.00 & 0.36 & 5.71 & 1.14 & 0.00 & 0.00 & 7.21 \\
\hline & Sirsa & 0.00 & 0.12 & 3.00 & 0.93 & 0.00 & 0.00 & 4.04 \\
\hline & Overall & 0.00 & 2.45 & 3.96 & 1.06 & 0.00 & 0.15 & 7.63 \\
\hline
\end{tabular}

*Number including calves and heifers 
Table.7 Composition of milch animals in the sample households (in percentage)

\begin{tabular}{|c|c|c|c|c|c|c|}
\hline Sl. No. & Type of farmers & State & Sahiwal & Desi & Crossbred & Buffalo \\
\hline \multirow[t]{4}{*}{1.} & \multirow{4}{*}{$\begin{array}{l}\text { Sahiwal rearing } \\
\text { farmers }\end{array}$} & Ganganagar & 53.27 & 32.38 & 3.40 & 10.96 \\
\hline & & Fazilka & 22.74 & 73.16 & 1.19 & 2.91 \\
\hline & & Sirsa & 63.74 & 1.61 & 17.61 & 17.05 \\
\hline & & Overall & 46.58 & 35.72 & 7.40 & 10.30 \\
\hline \multirow[t]{4}{*}{2.} & \multirow{4}{*}{$\begin{array}{l}\text { Crossbred rearing } \\
\text { farmers }\end{array}$} & Ganganagar & 0.00 & 35.21 & 46.36 & 18.43 \\
\hline & & Fazilka & 0.00 & 5.72 & 74.71 & 19.56 \\
\hline & & Sirsa & 0.00 & 1.49 & 76.17 & 22.34 \\
\hline & & Overall & 0.00 & 14.14 & 65.82 & 20.11 \\
\hline
\end{tabular}

Table.8 Number of households deriving income from alternative sources

\begin{tabular}{|c|c|c|c|c|c|c|}
\hline \multirow{2}{*}{$\begin{array}{l}\mathbf{S} \\
\mathbf{N}\end{array}$} & \multirow{2}{*}{ District } & \multirow{2}{*}{ Occupation } & \multicolumn{2}{|c|}{ SRF } & \multicolumn{2}{|c|}{ CRF } \\
\hline & & & No. & $\%$ & No. & $\%$ \\
\hline \multirow[t]{5}{*}{1.} & \multirow[t]{5}{*}{ Sri Ganganagar } & Crop production & 24 & 85.71 & 28 & 100.00 \\
\hline & & Livestock rearing & 28 & 100.00 & 28 & 100.00 \\
\hline & & Government Job & 2 & 7.14 & 0 & 0.00 \\
\hline & & Business & 0 & 0.00 & 1 & 3.57 \\
\hline & & Private Job & 1 & 3.57 & 0 & 0.00 \\
\hline \multirow[t]{5}{*}{2.} & \multirow[t]{5}{*}{ Punjab } & Crop production & 1 & 3.57 & 28 & 100.00 \\
\hline & & Livestock rearing & 100 & 100.00 & 28 & 100.00 \\
\hline & & Government Job & 0 & 0.00 & 0 & 0.00 \\
\hline & & Business & 0 & 0.00 & 0 & 0.00 \\
\hline & & Private Job & 0 & 0.00 & 0 & 0.00 \\
\hline \multirow[t]{5}{*}{3.} & \multirow[t]{5}{*}{ Haryana } & Crop production & 23 & 82.14 & 26 & 92.86 \\
\hline & & Livestock rearing & 28 & 100.00 & 28 & 100.00 \\
\hline & & Government Job & 1 & 3.57 & 0 & 0.00 \\
\hline & & Business & 2 & 7.14 & 1 & 3.57 \\
\hline & & Private Job & 3 & 10.71 & 0 & 0.00 \\
\hline \multirow[t]{5}{*}{4.} & \multirow[t]{5}{*}{ Overall } & Crop production & 69 & 82.14 & 78 & 92.86 \\
\hline & & Livestock rearing & 84 & 100.00 & 84 & 100.00 \\
\hline & & Government Job & 3 & 3.57 & 0 & 0.00 \\
\hline & & Business & 2 & 2.38 & 2 & 2.38 \\
\hline & & Private Job & 4 & 4.76 & 0 & 0.00 \\
\hline
\end{tabular}

$\mathrm{SRF}=$ Sahiwal Rearing Farmers, $\mathrm{CRF}=$ Crossbred Rearing Farmers 
Table.9 Average annual income of the sample households (Rs. per year)

\begin{tabular}{|l|l|r|r|}
\hline Sl. No. & \multicolumn{1}{|c|}{ District } & \multicolumn{1}{|c|}{ SRF } & \multicolumn{1}{c|}{ CRF } \\
\hline 1. & Sri Ganganagar & $5,65,607$ & $5,41,250$ \\
\hline 2. & Fazilka & $6,17,857$ & $7,45,001$ \\
\hline 3. & Sirsa & $9,11,071$ & $7,19,714$ \\
\hline 4. & Overall & $6,98,179$ & $6,722,26$ \\
\hline
\end{tabular}

Table.10 Standardized and Structure Coefficients

\begin{tabular}{|l|c|c|}
\hline \multicolumn{1}{|c|}{ Independent variable } & Standardized coefficients & Structure Coefficients \\
\hline Herd Size & 0.698 & 0.762 \\
\hline Education of household head & -0.354 & -0.516 \\
\hline Proportion of buffalo in total herd & -0.266 & -0.471 \\
\hline Livelihood diversification & 0.484 & 0.331 \\
\hline Size of the land holdings & & -0.211 \\
\hline Family size & & 0.208 \\
\hline Age of household head & & 0.173 \\
\hline Annual household income & & -0.145 \\
\hline Presence of pastures & & 0.021 \\
\hline
\end{tabular}

Table.11 Means of canonical variables

\begin{tabular}{|l|r|}
\hline & Canonical variables means \\
\hline Sahiwal Rearing Farmers & 0.513 \\
\hline Crossbred Rearing Farmers & -0.513 \\
\hline
\end{tabular}

Table.12 Test of significance

\begin{tabular}{|r|r|r|r|r|r|}
\hline Eigen Value & $\begin{array}{c}\text { Canonical } \\
\text { correlation }\end{array}$ & Wilk's Lambda & Chi-square & df & Sig. \\
\hline $\mathbf{0 . 2 8 9}$ & 0.474 & 0.776 & 40.879 & 4 & .000 \\
\hline
\end{tabular}




\section{References}

Dabhi, A.M., Rani, D. and Ghasura, R.S. 2018.Personal, socio-economic and psychological characteristics of crossbred cattle owners of Surat district in south Gujarat. Gujarat Journal of Extension Education. Special Issue on National Seminar organised in April, 2018.

Naveen, K.R., Veeranna, K.C., Gopala, G.T., Harisha, M.,Thirumalesh, T.,Shettar, V.B. and Udupaal, G.K. 2019.Socio Economic Profile of Farmers Rearing Gir Cattle in Karnataka.International Journal of Current Microbiology and Applied Sciences.8(10).

Raju, D. T., Pochaiah, M. and Reddy G. V. K.1996. Profile of respondents rearing crossbred cows. Indian Journal of Dairy Science, 49 (4): 230-233.

Sharma, S. and Sharma, F.L. 2005. Opinion of farmers towards rearing crossbred cattle in Girwa tehsil of Udaipur district of
Rajasthan. M.Sc. Thesis, MPUAT, Udaipur.

Sharma, S., Lakhera, J.P., Kaur, M., Bareth, L.S. and Monika. 2017. Socio-personal profile of women cattle owners in arid region of Rajasthan.Journal of Pharmacognosy and Phytochemistry.6(4): 556-558

Thesinguraja1, S., Mathialagan, P., Thilakar, P., Devendran, P. and Palanichamy V.2017.Socio-Economic Profile of Pulikulam Cattle Rearers in Madurai and Sivagangai Districts of Tamil Nadu, India.International Journal of Current Microbiology and Applied Sciences. 6(12):424-429.

Verma, A.K., Lal, N., Avhad, S.R. and Hari, R. 2014. Socio-economic status of farmers rearing Kherigarh, an indigenous breed of cattle. The Asian Journal of Animal Science, 9(2):134137.

\section{How to cite this article:}

Gunjan Bhandari and Chandel. B.S. 2020 Socio-economic determinants of breed choice- A case of Sahiwal vs. crossbred in India. Int.J.Curr.Microbiol.App.Sci. 9(01): 1427-1437. doi: https://doi.org/10.20546/ijcmas.2020.901.158 